\author{
Richard Miskolci \\ Universidade Federal de São Carlos
}

\title{
Machos e Brothers: uma etnografia sobre o armário em relações homoeróticas masculinas criadas on-line
}

\begin{abstract}
Resumo: A partir de uma etnografia feita com homens que se apresentam como Macho ou Brother em salas de bate-papo dirigidas a um público gay e bissexual da cidade de São Paulo, este artigo explora como eles articulam plataformas de busca de parceiros com o objetivo de criar relações em segredo. Esses homens apresentam-se e buscam parceiros que se descrevem como "discretos" e "fora do meio gay", forjando relações dentro do regime de controle da sexualidade conhecido como armário. Busco expor e compreender as normas de sexualidade e gênero que regem o armário desses usuários, os quais buscam manter seu status heterossexual mesmo tendo relações amorosas e/ou sexuais com outros homens.

Palavras-chave: sexualidade; internet; segredo; armário; relações homoeróticas masculinas; masculinidade heterossexual.
\end{abstract}

Copyright (๑) 2013 by Revista Estudos Feministas.

1 Para preservar o anonimato de meus colaboradores na etnografia, troquei seus nomes (os quais em sua maioria são inventados) por outros fictícios.

${ }^{2}$ Este artigo apresenta os resultados preliminares da pesquisa Desejos em rede, financiada pelo CNPq por meio de bolsa de produtividade em pesquisa. Agradeço as sugestões d@s pareceristas da REF e também as de lara Beleli, Larissa Pelúcio e dos membros do Grupo de Pesquisa Corpo, Identidades e Subjetivacões (UFSCar).

${ }^{3}$ George CHAUNCEY, 1995; Didier ERIBON, 1999; e James GREEN, 2000.
"Se não fosse pela internet eu não teria conhecido outros caras... Ela [a rede] é o melhor lugar que eu encontrei pra mim", relata Alex, ${ }^{1}$ auditor de 33 anos, frequentador assíduo de salas de bate-papo gays de São Paulo. Sua fala ajuda a compreender como os sites da internet em que homens procuram relações amorosas ou sexuais com outros homens podem ser compreendidos como o capítulo mais recente da história dos espaços para a busca de parceiros do mesmo sexo. ${ }^{2}$

Historicamente alijadas da maior parte do espaço público, as homossexualidades tenderam a se restringir a certas regiões das grandes cidades. ${ }^{3}$ Em São Paulo, a restrição social a essas relações incentivou o cruising e a formação do espaço que, ao menos até a década de 1980 , se denominava de gueto, ${ }^{4}$ mas progressivamente deu lugar a um circuito comercial complexo e geograficamente amplo 
${ }^{4}$ Néstor PERLONGHER, 2008.

${ }^{5}$ Júlio Assis SIMÕES e Isadora Lins FRANÇA, 2005.

- Segundo dados do lbope, em 2008, quando esta investigação se iniciou, 41,5 milhões de brasileiros tinham acesso à internete, em maio de 2010, segundo a empresa comscore, esse número já teria atingido 73 milhões de usuários. A rede se revela cada vez mais representativa da pirâmide socioeconômica e até mesmo demográfica do país, ainda que sua importância seja maior no Sudeste e na faixa etária da juventude. Por volta de dois terços dos usuários se concentram nesta região e têm entre 15 e 34 anos. Cerca de $60 \%$ da população do Sudeste tem acesso à rede, sendo esse número ainda mais alto em São Paulo, foco desta pesquisa.

${ }^{7}$ Nicholas BURBULES, 2004; Sarah HOLLOWAY Y Gill VALENTINE, 2003; e Larissa PELÚCIO, 2005.

${ }^{8}$ Richard MISKOLCl, 2009; Eve Kosofsky SEDGWICK, 2007; e Steven SEIDMAN, 2004 conhecido como "meio gay". ${ }^{5}$ Associada a esse circuito, a partir de 1997, a internet comercial iniciou seu processo de expansão no Brasil, recriando, mas sobretudo ampliando o espaço para a socialização homoerótica.

Os espaços on-line se estendem e se aproximam da maioria que vive na periferia, em cidades médias, pequenas ou mesmo na zona rural. Além disso, para pessoas que jamais quiseram (ou puderam) se expor de forma a frequentar algum local claramente gay, a web criou a possibilidade de criarem redes de relações. Esses sujeitos, frequentemente marcados por uma origem social conservadora, encontraram na internet uma forma de conhecer parceiros e até fazer amizades sem o ônus da exposição de seus interesses eróticos no espaço público. ${ }^{\circ}$

Curioso sobre esse cenário, desde o final de 2007, pesquiso como usuários homens adultos articulam o uso de plataformas da rede em busca de parceiros sexuais e amorosos do mesmo sexo. A investigação associa leituras sobre o tema e o desenvolvimento de longa etnografia que tem permitido criar contatos pessoais para acompanhar a vivência dos pesquisados. Desde o início, eles demonstraram que o uso da rede é feito para a criação de contatos face a face. As falas de meus colaboradores reiteraram essa relação intrínseca entre vida on-line e off-line, pois o uso da internet costuma se associar à constituição de contatos e redes de relacionamento que se estendem para a vida social.?

Também salta aos olhos a recorrência, em anúncios sexuais, na apresentação em bate-papos ou mesmo em perfis de redes sociais voltadas para um público homossexual, a afirmações como "sou fora do meio" ou "procuro alguém fora do meio, como eu". Diante desse aparente paradoxo de os usuários estarem dentro do que procuram e negarem surge a questão: o que estaria por trás da autoapresentação recorrente como "fora do meio"? A primeira pista está na forma como meus colaboradores buscam relações face a face que possam reproduzir as características que as originavam online, ou seja, a possibilidade de acesso individualizado e anônimo. Isso demonstra a persistência do armário na era das mídias digitais.

Eve Kosofsky Sedgwick define o armário como o regime de controle da sexualidade que rege e mantém a divisão binária hétero-homo da sociedade Ocidental desde fins do século XIX. O armário se caracteriza por um conjunto de normas nem sempre explícitas, mas rigidamente instituídas que faz do espaço público sinônimo de heterossexualidade, relegando ao privado as relações entre pessoas do mesmo sexo. ${ }^{8} \mathrm{~A}$ vivência da homossexualidade "em segredo" constitui uma característica histórica, daí a 
9 SEDGWICK, 2007, p. 30.

${ }^{10}$ Michael LYNN e Rosemary BOLIG, 1985. afirmação de Sedgwick de que a homossexualidade e o segredo sexual têm a mesma origem:

Ao final do século XIX, quando virou voz corrente - tão óbvio para a Rainha Vitória como para Freud - que conhecimento significa conhecimento sexual e segredos, segredos sexuais, o feito gradualmente reificante dessa recusa significou que se havia constituído, de fato, uma sexualidade particular distintamente constituída como segredo. ${ }^{9}$

A partir das luminosas palavras de Sedgwick, é possível começar a compreender o que reside por trás da afirmação recorrente "sou fora do meio", atentando para como essa aloca o desejo por pessoas do mesmo sexo no segredo, conformando-o a expectativas historicamente criadas de que essas relações deveriam permanecer invisíveis no espaço público e restritas à vida privada dos envolvidos. O contato pela web se associa à percepção de que ser ou estar "fora do meio" é ser "normal" e ter a capacidade de desaparecer como parte da maioria (compreendida como hétero).

Em outras palavras, um grande número de usuários de internet brasileiros afirmam que é possível (e pressupõem que desejável) que, mesmo se relacionando com pessoas do mesmo sexo, não sejam reconhecidos como homossexuais. Daí surge a questão: por que seus relatos revelam tantas dificuldades e sofrimentos nas tentativas de viver assim? Buscando responder a essa questão, apresento a seguir alguns dados desta etnografia desenvolvida a partir das salas de bate-papo mais populares entre os internautas de São Paulo. Iniciarei explicitando os procedimentos metodológicos que segui para adentrar nesse universo das relações criadas on-line. A seguir, analiso os perfis de homens que se apresentam como Macho ou Brother e cujas vidas articulam relações com mulheres e homens. Por fim, ensaio uma análise sobre os valores que regem as vidas desses homens que buscam conciliar seu anseio de aceitação social com seus desejos homoeróticos.

\section{Caindo na rede}

Há diversas plataformas on-line segmentadas para um público homossexual como sites de anúncios, redes sociais e salas de bate-papo. Michael Lynn e Rosemary Bolig,,$^{10} \mathrm{em}$ outra época e contexto, enumeraram as vantagens de se estudarem anúncios de busca de parceiros/as, sobretudo o fato de que os pesquisados não sabem que são objeto de análise, o que tornaria os dados mais espontâneos. Após o advento da internet, a interatividade se impôs como mais relevante para pesquisas sobre a busca de parceiros, particularmente em nosso país, onde a adesão à rede é 
${ }^{11}$ María Elvira DÍAZ-BENíTEZ, 2010.

marcada pelo uso de plataformas de socialização, o que explica a popularidade das salas de bate-papo.

Em São Paulo, as salas mais populares estão na seção de sexo. Homens que procuram relações com outros homens circulam predominantemente entre as salas voltadas para gays e bissexuais. Iniciei minha incursão por elas, entre dezembro de 2007 e junho de 2008, seguindo dois procedimentos complementares: um, de aproximação pelo conteúdo "externo" da plataforma (dados possíveis de acessar sem interação com os usuários) e, o segundo, de "imersão" no campo. Entrei nas salas de bate-papo várias vezes ao dia para me familiarizar com a plataforma e tentar mapear seus frequentadores.

Após essa aproximação inicial, "imergi" no campo entrando nas salas para "dialogar" com os usuários, ter acesso a seu vocabulário e valores. A primeira constatação foi a de que, apesar de os usuários terem perfil muito heterogêneo, há marcante presença de homens que não têm sociabilidade gay na vida cotidiana, como os comprometidos com mulheres. Também são comuns recémchegados a São Paulo ou que, mesmo morando nela há longo tempo, têm origem no interior ou em outros estados brasileiros. Tentei me identificar como pesquisador, o que resultou em formas diversas de rejeição: do bloqueio de minhas mensagens à frequente recusa da conversa ou interações pouco naturais e limitadas. Concluí que as características desse campo permitiam interação anônima, acessar suas experiências cumprindo o compromisso ético de preservar a identidade e as informações pessoais de meus colaboradores para não os expor a qualquer constrangimento.

As experiências relatadas, somadas à busca de uma interação mais simétrica com os pesquisados, me levaram a optar por uma observação "participante". Essa estratégia investigativa permitiu preservar e apreender os códigos culturais em mais de cem entrevistas feitas na própria plataforma até que, depois, em interações mais próximas, por Messenger ou pessoalmente, revelei minha condição de pesquisador e pedi autorização para manter contato, entrevistá-los e acompanhar suas vivências. Assim, pude interagir de forma "acompanhante" nos termos da antropóloga María Elvira Díaz-Benítez, ${ }^{11}$ pois apenas conversei com eles, entrevistei alguns e acompanhei um pouco de suas vidas.

Para começar, precisava de um apelido para me tornar um usuário do bate-papo e interagir. Fiz muitos testes até optar pelo uso de nomes próprios, os quais se impuseram como meio para não me apresentar como alguém que buscava algum tipo determinado de parceiro. Dentre os nomes testados, descobri que Antonio evocava idade mais 
avançada e Rafael juventude, enquanto nomes como Paulo e Marcelo não pareciam associados a nenhuma faixa etária ou origem social clara. Passei a frequentar as salas com esses apelidos "neutros" e teclar com usuários os mais diversos até focar nos que se apresentavam como Macho e Brother devido à constante afirmação deles de serem "fora do meio" e buscarem "alguém similar".

Passei semanas conhecendo os códigos de sociabilidade daquele ambiente por meio de conversas que constituíram entrevistas prospectivas, já que, nas salas, as conversas tendem a ser genéricas e curtas. A maioria dos usuários tende a usar a plataforma apenas como meio de seleção de pessoas com as quais pretende ter interações privadas via Messenger. Foi por meio desse programa que consegui obter 13 longas entrevistas semiestruturadas, nas quais deixei expressarem-se o mais livremente possível, de forma a reconstituir seu perfil social, interesses, visões sobre a internet e relações ali forjadas. Também me encontrei pessoalmente, conversei diversas vezes e acompanhei por mais de dois anos - com proximidade e frequência variada - a vida de quatro desses homens. De qualquer forma, não foram apenas os que entrevistei ou conheci face a face os que me auxiliaram a adentrar nessa esfera de sociabilidade, muitos contatos somente online e com menor exposição, quer deles, quer minha, terminaram por prover informações ricas e esclarecedoras.

Constatei que - apesar de o chat estar na subdivisão Sexo do site e serem comuns apelidos evocando tipos, posições e práticas sexuais - é elusivo associar esses espaços exclusivamente à busca de sexo. Não por acaso, uma das primeiras questões que surgem ao se iniciar uma conversa é: "o que você procura?". Respostas usuais são "o que rolar" ou "alguém interessante para ver o que acontece", o que pode sinalizar interesse para além do sexo imediato. Alguns afirmam que as amizades ali constituídas costumam ser apenas "um prêmio de consolação" depois de encontros que não geraram uma relação sexual ou amorosa. Outros avaliam que esses contatos auxiliam a diminuir a solidão ou a suportar a "tensão" que vivenciam tentando gerir uma vida oficial com uma mulher juntamente com relações com outros homens em segredo.

Considero que foi esse anseio por alguém para conversar que permitiu iniciar o contato com meus colaboradores na pesquisa. Minha interação no bate-papo começava com os usuais cumprimentos e eu procurava ser o primeiro a perguntar o que o outro buscava, pois é quase praxe responder "o que rolar", "um brother firmeza" e outras expressões que dão abertura a uma conversa que vá além da busca de sexo. A partir daí, para manter a conversa, tinha que dar informações sobre mim, as quais buscava apresentar de forma 
${ }^{12}$ Minha posição era dolorosa porque adentrei nesse espaço da "tensão" e da "dor" que compõe seus "armários", desenvolvendo uma espécie de etnografia do sofrimento, a qual gerou um artigo sobre desejo e solidão (MISKOLCl 2008). ponderada. Sem foto ou som, é muito mais fácil entreter um diálogo com homens que - possivelmente - no cotidiano não se sentiriam à vontade comigo, um intelectual que não se encaixa em seu padrão de masculinidade. Essa "descorporificação" inicial era tão mais bem-sucedida quanto gerava contato mais "próximo" pelo Messenger.

O contato evoluía dentro dessa gramática da existência "descorporificada" no bate-papo, passando pela corporificação imagética e em tempo real no Messenger até adquirir, aos poucos, certa "intimidade" com meus interlocutores graças à sua predisposição a conversar sobre suas histórias de vida. De certa maneira, tratavam-me como uma espécie de psicanalista deles e, quanto mais contínuo o contato, surgiam demandas de que eu os auxiliasse a entender por que agiam assim. Buscavam sentir-se melhor consigo próprios sem alterar a forma como agiam.

Minha posição de intelectual valeu-me por não ser atraente em termos eróticos para homens que buscam, predominantemente, parceiros que gostem de futebol, pratiquem esportes ou tenham em comum com eles atividades e interesses nada acadêmicos. Sem ser visto como parceiro em potencial, mas como "inteligente", adquiri - na visão deles - um status de respeitabilidade que me tornou um misto de confidente e analista. Assim, sempre a partir do consentimento deles, mantive contato e busquei ouvir suas histórias e como eles mesmos as interpretavam. A maioria as apresentava de forma pragmática e integrada ao seu modo de viver, mas progressivamente narrava estórias de relações que se tornaram frequentes e viraram "rolos" ou "casos". A partir daí, seus relatos materializavam dilemas morais, temores de serem descobertos e, em alguns casos, "consciência pesada".

Demorei a perceber que suas queixas constantes de solidão e sofrimento, por mais verdadeiras que fossem, deviam ser relativizadas como mecanismo de expiação de culpa e criação de empatia para com suas vidas. ${ }^{12}$ Terminei por constatar que utilizavam essa "condição difícil" para barganhar as condições nos relacionamentos secretos que criavam e tentaram fazer algo similar comigo. Em outras palavras, esses homens realmente sofrem e se sentem solitários, mas não são simples vítimas de uma ordem social heterossexista, pois detêm agência. O sofrimento os alivia ou os "desculpabiliza" por agirem em desacordo com valores familiares, e a solidão também precisa ser compreendida como constitutiva de uma masculinidade que recusa negociar seus desejos ou afetividades com outras pessoas.

O "peso emocional" que marca suas vidas tornava difícil o convívio com eles, pois compreensivelmente queriam dialogar comigo em troca de auxílio e conselhos sobre seus dilemas morais. Na posição de pesquisador, passei a 
enfrentar a difícil arte de equilibrar análise e sinceridade quando me demandavam opiniões sobre suas atitudes com namoradas e amantes. Tive que aprender a lidar com um acúmulo de tensões, tanto as que eles me transferiam quanto as que vivenciava como pesquisador tendo que manter contatos em um campo etnográfico marcado por sofrimentos, ansiedades e suspeitas. O melhor recurso que aprendi a acionar em momentos difíceis foi o de diminuir a interação alegando excesso de trabalho ou outros compromissos.

Além disso, o que mais impediu que o campo se estendesse continuamente foi a tendência de eles terem um comportamento pendular entre a vida apenas com uma parceira mulher e a que concilia relações com mulheres e homens. Inicialmente, pensei que isso explicaria um recurso à rede apenas quando insatisfeitos na vida sexual com mulheres, mas, depois, constatei que esse comportamento tinha outra origem. Meus colaboradores, em particular os que se apresentam como Machos e Brothers, tendem a priorizar as relações com mulheres, as quais se confundem com os eventos familiares nos quais se engajam com prazer, relegando a um segundo plano as relações com outros homens. Dessa maneira, em períodos de muita demanda familiar suspendem temporariamente a busca de parceiros homens e mesmo a sociabilidade on-line.

O melhor recurso para ganhar a confiança de meus colaboradores foi a disposição de conhecê-los pessoalmente seguindo suas exigências. Foi assim que, sempre a partir do convite de um deles, marcamos encontros em local público e longe de sua área de circulação cotidiana. Em graus variados, o contato face a face permitiu que a "amizade" on-line continuasse e até se tornasse mais sólida. Avalio que a possibilidade de conversar com um "especialista" parece ter sido meu principal atrativo, o que gerou mais afinidade com os de classe média, mais ou menos familiarizados com um vocabulário psicanalítico.

Apesar da curiosidade e do interesse em conversar comigo, constatei que os que conheci pessoalmente temiam arriscar-se, por isso busquei ser o mais transparente possível, adotando práticas que iam desde apresentar minha carteira funcional até contar coisas pessoais para criar confiança. Tive que ser muito franco mesmo descobrindo, não sem surpresa e certo desapontamento, as mentiras ou as ficções que eles me apresentavam. Isso era perceptível nas incoerências de discurso e nos lapsos de fala, nas histórias que se modificavam com o passar do tempo, deixando entrever que eu mesmo estava a vivenciar a forma como eles se apresentavam tentando criar vidas duplas que gostariam paralelas, mas, no fundo, se cruzavam a todo momento. 
${ }^{13}$ Carolina PARREIRAS, 2008.

Seus períodos de alta frequência on-line facilitaram meu trabalho e se constituíram em um dado revelador que demorei a decifrar. Em suas vidas marcadas pelo desejo secreto por outros homens, a internet entra como importante elemento destensionador, pois nas plataformas on-line é que se sentem com mais controle e capacidade de evitar que seus desejos homo interfiram em sua vida cotidiana. Com esse intuito, a maioria articula várias plataformas da internet em sua vida social, mas, por vivenciar sua sexualidade de forma secreta, tende a duplicar seus perfis, mantendo um "oficial" que atende às demandas de conformidade aos valores sociais e outro no qual expressam seus interesses secretos.

Uma mesma pessoa costuma ter dois perfis no Facebook, um para adicionar como amigos membros da família e colegas de trabalho e outro que podemos compreender, a partir da classificação de Carolina Parreiras, ${ }^{13}$ como Masks, perfis que não podem ser chamados de falsos, pois revelam mais sobre os desejos e as aspirações dessas pessoas do que o oficial. Também pode ter um ou mais anúncios de busca de parceiros (um "sério" e outro voltado para encontros sexuais anônimos), frequentar chats e acrescentar contatos vindos de todas as plataformas anteriores em seu Messenger. Também nesse caso, a maioria relata ter dois: um para a família, amigos e colegas de trabalho, e outro para os contatos amorosos ou sexuais com pessoas do mesmo sexo.

Se na era pré-internet faltavam contatos ou eles eram reduzidos, hoje, ao menos em uma metrópole como São Paulo, eles abundam e a escolha se torna fundamental. Nos bate-papos, colocam em prática uma seleção progressiva que começa com a análise da descrição física do interlocutor, à qual se segue uma interação privada em que fornecem o link para um perfil no Facebook ou em algum site de anúncio de busca de parceiros. Se o interesse for mútuo, trocam identidades para adicionarem-se no Messenger ou Skype, em que cada vez mais usam a câmera e o microfone para começar a se conhecer.

\section{Machos e Brothers}

Eduardo, um administrador de empresas de 26 anos e morador de um bairro de classe média alta de São Paulo, costuma se apresentar como Brow nas salas de bate-papo gays e bissexuais. Nascido no Mato Grosso do Sul, cresceu em uma família abastada e se mudou para São Paulo para fazer cursinho, depois faculdade privada e, por fim, quando o conheci, vivenciava um processo de consolidação profissional. Dizia namorar há quase dois anos uma jovem 
arquiteta e ter se iniciado recentemente em relações com outros homens. Demorou a me mostrar suas fotos, mas, por fim, chegou até a abrir sua câmera, quando constatei que se descrevera sem mentir. É um homem moreno claro, aparentemente alto e másculo, com uma grande tatuagem no braço direito. Usava roupa esportiva e boné quando me cumprimentou com gestual de "firmeza". Surpreendeu-me quando mostrou dois porta-retratos com fotos da namorada. Gostava de esportes, viajar com ela para o litoral e sair em baladas com seus amigos, mas - segundo dizia - tinha cada vez mais interesse em encontrar um Brother como ele.

Como Eduardo, são frequentes os rapazes que se apresentam como Brother, Brow e o menos privilegiado Mano (variação do mesmo nickname, mas que denota origem nas classes populares ou na periferia). O que unifica a maioria dos usuários que utilizam esses apelidos é a busca de reconstituição, na internet e particularmente nos contatos homoeróticos, de uma fraternidade idealizada cujo valor comum é a masculinidade compreendida como a identificação com os valores dominantes que a qualificam como hierarquicamente superior ao feminino e os alça ao compartilhamento do poder sobre as mulheres.

É comum que se apresentem como "machos", "discretos", "que curtem mina" ou mais raramente como bissexuais. Em sua imensa maioria, procuram um parceiro para sexo ou relacionamento com o qual possam circular no espaço público como se fossem apenas amigos. Eduardo, por exemplo, observa: "pra mim, o cara tem que ser brother, aí dá pra gente sair sem suspeita, tipo dois amigos que saem pra paquerar mulher...". A experiência de sair e paquerar mulheres para "provar" sua aparente heterossexualidade torna esses homens mais atraentes para seus parceiros em uma dinâmica aparentemente paradoxal, mas esclarecedora sobre o tipo de desejo erótico que a molda. Em outro momento, Edu acrescentou: "o que importa é rolar algo quando a gente está sozinho".

O e-mail de entrada de "MachoGato27" no Messenger é o de um deus mitológico com face mutante e sua identidade no MSN é um anônimo "Eu". Apresenta uma foto a distância na qual permite apenas ver o corpo de um homem branco, de barba, alto e malhado, mas diz abrir a câmera e mostrar o rosto quando está interessado em um possível parceiro. Originalmente de Minas Gerais, ele reside há alguns anos entre o Centro e a Zona Sul, apresentou-se como Caio, dizia ter 27 anos e, algum tempo depois, contou cursar pós-graduação em uma reconhecida universidade de São Paulo. Segundo ele, buscava relações on-line porque considerava ter o direito de viver seus desejos sem culpa e tampouco sem prestar contas a ninguém. Caio, assim como outros que se apresen- 
tam como Macho ou variações (MachoGato, MachoSarado etc.), não buscava necessaria-mente um parceiro com o qual sairia em público.

Assim como Eduardo e Caio, os homens com os quais convivi mais proximamente eram brancos, tinham nível universitário, exerciam profissões consideradas tradicionais (advogados, médicos, executivos), vinham de famílias católicas, de classe média ou alta e cresceram em cidades pequenas ou médias do interior ou de estados vizinhos. A maioria conhecia boates e outros locais de frequência gay de São Paulo, mas considerava esses espaços fúteis e frequentados por homens com os quais não sentiam afinidade. Pareciam-me sinceros nessa visão crítica sobre o "meio", assim como se diziam incompletos na vida hétero, portanto justificando a busca por um "lugar" intermediário na internet.

Ainda que os perfis dos Brothers e dos Machos sejam muito próximos e até se misturem, parecem predominar entre os que se apresentam como Brother a busca de constituição de algum laço e a possibilidade do encontro em público, enquanto entre os Machos predominam encontros anônimos diretamente na casa de um dos parceiros. Enquanto boa parte dos Brothers busca um "parceiro para sexo fixo", o que seria errado confundir com "relacionamento" ou "namoro" no padrão hétero, a maioria dos Machos afirma procurar sexo "em sigilo" ou "sem compromisso". De qualquer forma, pode ser elusivo associar os apelidos ferreamente a um único comportamento, assim como a uma faixa etária definida. O Brother de hoje pode ser o Macho de amanhã (ou vice-versa) e, apesar de expressarem formas de interação e objetivos diferentes, são apelidos gêmeos em um aspecto: o alto valor que atribuem à masculinidade heterossexual como compreendida no Brasil.

Os usuários que se apresentam como Brother e Macho têm em comum um culto da masculinidade dominante que se revela na forma como falam (têm ou buscam apresentar voz grave, uso de gírias "masculinas" e palavrões), se vestem (usam roupas esportivas no cotidiano e se vestem com certa formalidade no trabalho), em sua corporalidade (usam cabelo curto, barba, cavanhaque, alguns têm tatuagens) e, sobretudo, em valores que reiteram em suas falas como discrição, maturidade e honra associados a um claro desprezo compartilhado com relação a "efeminados", definidos por eles como os que parecem gays ou são "assumidos". Tanto nas interações no chat quanto em seus anúncios em sites é possível reconhecer o que associam a "efeminados" em afirmações como: "Não curto pessoas idiotas nem afeminados", "Tô fora de afeminado e drogado de plantão", ou ainda, "Tô fora de viados da noite, bichinhas afetadas ou que se dizem machos e na hora vêm com aquela roupa fashion e com aquela voz de pato".

310 Estudos Feministas, Florianópolis, 21 (1): 301-324, janeiro-abril/2013 
${ }^{14}$ Voon Chin PHUA, 2002; e Horácio SÍVORI, 2010.
Esses usuários acreditam que a internet lhes dá autonomia com relação às normas sociais, característica que se mescla ao comportamento masculino dominante que subalterniza interlocutores. Assim, não é mero acaso o caráter quase unilateral com que parte desses internautas lida com plataformas como bate-papo, o que constatei também moldar sua sociabilidade off-line. Demandam descrições pormenorizadas, mas se furtam a fornecê-las, assim como exigem fotos ou câmera para conversar no Messenger sem necessariamente possuí-las ou disponibilizá-las. Isso revela como a internet potencializa a tendência a idealizar sua própria inserção social, alçando-os ao topo de uma hierarquia que, sobretudo na interação face a face, tende a ser tensionada.

Nos encontros sexuais anônimos predomina o que alguns definem e desejam como "adrenalina", uma excita-ção sexual concentrada, mas mesmo os que dizem buscar sexo sem compromisso "de vez em quando" parecem priorizar alguma forma de encontro prévio, mesmo que seja rápido. Definem o encontro cara a cara como "o teste final" para avaliar se "dá pra transar", mas também os que podem até se tornar "um amigo para sexo fixo" (fuck buddy) ou, mais raramente, algo mais. A maioria faz contatos prévios por telefone para avaliar o tom de voz e a conversa, ou seja, se o outro fala como "macho" (o que é valorizado) ou se "fala mole" ou "mia" (termos pejorativos que associam o outro ao efeminamento e, sobretudo, à autodenunciação como gay). O "conjunto" procurado no parceiro soma aparência física atraente, leia-se, a de uma masculinidade heterossexual, voz grave, conversa que expresse valores e experiências comuns, como manter relações com homens em segredo.

Suas descrições da "estranheza" do encontro têm relação com a transposição da relação do espaço aparentemente secreto da rede para o da temida exposição pública. Quando marcam um encontro em local público, relatam a excitação mesclada ao cuidado na conversa, nos olhares e no gestual, o que guiará a avaliação recíproca sobre a conformação a imagens dominantes de masculinidade, fato observado por pesquisas em outros contextos nacionais. ${ }^{14}$ Nesse caso, a masculinidade é o critério para avaliar se o parceiro em potencial "passa por hétero", é "discreto", o que também envolve sinais de origem socioeconômica, étnico-racial e cultural. Um rapaz que seria avaliado como "discreto", ou seja, "macho", por outro de classe média alta poderia ser considerado "suspeito" de acordo com padrões de um Mano, jovem das classes populares da periferia que, frequentemente, é mulato ou negro. A "masculinidade" é, portanto, negociada e imaginada diferentemente segundo o contexto e a origem sociocultural dos envolvidos. 
15 É importante lembrar que as publicações e os sites gays costumam estampar modelos heterossexuais em suas capas e páginas.
Na internet, e em especial nos sites voltados para um público masculino, o corpo parece ganhar até mais centralidade do que na vida cotidiana. Em todas as plataformas encontrei uma alta demanda por boa aparência e medidas modelares, o que torna compreensível a prioridade que meus colaboradores atribuem à aparência física na seleção de parceiros, em especial o pré-requisito de que sejam másculos. Descrevem a masculinidade que os atrai por meio de imagens correntes em sites gays, em geral materializadas em corpos atléticos que - supostamente - não teriam nenhum sinal visível de homossexualidade, o que leva a refletir sobre como a masculinidade que desejam é a que se vende midiaticamente como passando por hétero. Trata-se, portanto, de uma masculinidade idealizada e disseminada pela mídia que buscam encarnar neles próprios e encontrar nos parceiros que buscam on-line. ${ }^{15}$

Os insucessos nos encontros costumam ser atribuídos ao fato de que o outro não correspondia às expectativas criadas on-line, em que homens costumam se apresentar como mais jovens, altos, fortes ou másculos do que provavelmente serão avaliados frente a frente. $O$ fato é que muitos dos que conheci tendem a buscar (e até exigir) do outro padrões corporais e culturais que eles próprios não atendem. Além da alta demanda por atratividade física e masculinidade, também é perceptível uma tendência a procurar parceiros que também se relacionem com mulheres ou, ao menos, mantenham uma vida aparentemente hétero.

A constatação anterior se relaciona à percepção de que, a partir do encontro, se deparam com a suspensão da imaginada autonomia individual, a qual passa a ser "negociada" para evitar o risco que a internet parecia suspender: o de ser "descoberto". Assim, o "caso" - para ser bem-sucedido - exige a constituição de certo compartiIhamento desse perigo, pois a relação iniciada com o contato pela internet cria uma nova situação: um armário para dois. Ao temor da exposição a conhecidos se soma a dependência do outro para a manutenção de seu segredo, o que tensiona o envolvimento, pois aquele a quem se deseja também é aquele que se teme (por conhecer seu segredo).

Dos 13 entrevistados em profundidade, cinco disseram ter companheira no momento, mas apenas um (solteiro na época da pesquisa) conversou mais sobre a situação da parceira mulher que convive - aparentemente sem nem imaginar - com um homem que se interessa por pessoas do mesmo sexo. Trata-se de um auditor que na época tinha 29 anos e morava em um bairro de classe média da Zona Norte de São Paulo. Alex nasceu e viveu a maior parte de sua vida em uma cidade média do interior do estado, onde chegou 
${ }^{16}$ Sobre a infidelidade nas relações amorosas brasileiras contemporâneas em uma perspectiva apenas heterossexual, consulte Miriam GOLDENBERG, 2010. a se casar, teve uma filha, mas - segundo conta - a "sensação de culpa" por trair a esposa com outros homens o levou à terapia e ao uso de antidepressivos. Um dia decidiu se separar e, às vésperas de completar 30 anos, mudou para São Paulo buscando sua primeira relação amorosa duradoura com outro homem. Mesmo longe da família, que deixou no interior, e vivendo em uma cidade com uma extensa e variada sociabilidade gay, Alex continuou a buscar um parceiro pela internet, segundo ele porque "Não me sinto normal no meio gay.... Não vivo na academia e me preocupo mais com meu trabalho do que em viajar, me vestir na moda ou ir numa boate nova por semana".

Assim como Alex, a maioria de meus interlocutores prioriza o contato na rede para manter suas vivências homossexuais em segredo. Os perfis duplos, Messengers duplos, enfim, revelam a tentativa de criar uma existência paralela cuja centralidade emocional tensiona o cotidiano em que lutam para se inserir como pessoas "normais", discretas, heterossexuais. Essa dualidade é mais ou menos aceita como inevitável, e é visível como o trabalho constante de manutenção das vivências homo em segredo se pauta pela prioridade que conferem à sociabilidade heterossexual, em especial a familiar.

Ainda que afirmem a importância das relações homoeróticas em suas vidas, vivem relegando-as ao segundo plano. Essa maneira de organizar suas relações parece contradizer seus discursos, mas um olhar mais atento pode perceber que, mesmo mantidas em segredo e ocupando menos tempo em sua vida cotidiana, as relações secretas realmente desempenham um papel fundamental para eles. Marcados por uma concepção de masculinidade com fortes raízes históricas na sociedade brasileira, sentem-se mais integralmente homens quando vinculam à relação oficial com a parceira uma outra. ${ }^{16}$ No entanto, nesse caso a outra é um homem, o que modifica os termos de negociação do segredo.

Exercitando uma masculinidade culturalmente reconhecida com outro homem no lugar da amante, passam da afirmação de sua virilidade para o risco de vê-la contestada. Assim, a busca de meus colaboradores por constituir vidas paralelas traduz um desejo de manutenção de sua masculinidade, no fundo sob ameaça, o que os leva a reforçar o controle do parceiro. Mesmo omitindo dados sobre a vida hétero, eles permanecem tendo que conciliar vidas que se cruzam a todo momento. Temem encontrar alguém conhecido no lugar errado, mas - frequentemente o que mais os ameaça são eles mesmos, daí se imporem um constante autoexame para não traírem a si mesmos. O que torna compreensível o expediente de alguns de meus 
${ }^{17}$ Georg SIMMEL, 2010, p. 40. pesquisados de adotarem nomes falsos em seus contatos com outros homens (e mesmo comigo).

De meus colaboradores, Caio foi o que mais buscou contato e tentou me convencer de que era um "amigo", mas só me revelou seu nome real seis meses depois de nos conhecermos. Como outros, também mentira a idade já tinha mais de 30 anos), omitia tudo o que se relacionava à sua namorada e inventava detalhes sobre sua vida pessoal e profissional que, depois, confundia. Assim como a identidade de entrada em seu Messenger evocava uma figura de muitas faces, vivia manipulando a namorada e os amantes com os quais ensaiava relações secretas. Comigo, suas omissões e mentiras visavam manter minha atenção e tentar que o auxiliasse a se sentir mais confortável consigo mesmo.

Após mais de um ano de contato, Caio, ao perceber que não aprovava como vivia, bloqueou-me em seus Messengers, passou a ocultar suas relações com outros homens, mas fez questão de manter contato por diversos meios, em especial por telefonemas e envio de SMS (mensagens por celular). Afirmava ser meu amigo, no entanto, jamais me apresentou à namorada, à família ou aos amigos, o que terminou por me auxiliar a perceber como as estratégias que esses homens desenvolvem para controlar seus segredos afetam todas as suas relações. Temerosos sobre a possibilidade de que seus casos com outros homens ameacem sua imagem pública heterossexual, tendem a desconfiar das pessoas que conhecem on-line, fazendo uso da mentira para se proteger. Segundo Georg Simmel, a mentira é o outro lado da vergonha, uma forma de limitar o conhecimento alheio sobre si mesmo, ou melhor, "uma técnica positiva e agressiva que persegue seu propósito mediante um uso simples do segredo e da ocultação". ${ }^{17}$

A web se revela uma ferramenta com características próprias, e seu uso por esses homens se associa a um exercício de uma masculinidade sob constante ameaça. A aparente segurança on-line não tem paralelo no off-line, daí os relatos de manobras mirabolantes para evitar o risco de que suas relações com outros homens os exponham ao escrutínio de conhecidos, sobretudo familiares e colegas de trabalho. Alex, por exemplo, dividia os contatos em dois números de celular diferentes, mentia sobre o bairro em que morava para os homens com quem saía e só marcava encontros ou saía com algum caso evitando os locais em que poderia deparar-se com conhecidos.

$\mathrm{Na}$ rede de relações que criou desde que mudou para a capital, parecem predominar outros que adotam táticas similares e que, estrategicamente, tendem a manter mesmo esses "amigos" a certa distância de seu núcleo familiar. Segundo ele, o fato de ter família no interior lhe dá mais

314 Estudos Feministas, Florianópolis, 21 (1): 301-324, janeiro-abril/2013 
segurança em comparação a seus amigos paulistanos. A imagem de "separado" com filha garante seu status na cidade de origem, mas, recentemente, relatou-me sentir pressão para apresentar aos pais a sua namorada. Ao indagar, "qual?", ele riu e revelou que tinha um caso com uma colega de trabalho. Atualmente "namorando sério" um rapaz bem mais novo, tem se sentido pressionado na família e no trabaIho e sob o risco de que alguém descubra a relação, pois seu companheiro não tem namorada e quer morar junto. Dividido entre pressões, riscos e desejos, já parece reencontrar um velho e conhecido dilema que acompanhei em muitos relacionamentos criados na internet.

Grande parte dos relatos de insucessos relacionais tem como clímax o momento em que eles ou seus parceiros encararam a possibilidade de serem vistos publicamente como homossexuais. Nos vários casos que acompanhei, distanciaram-se ou cortaram contato com o amante homem $\mathrm{e}$, depois de algum tempo, retornaram à internet em busca de outro. Suas reclamações ou críticas às relações forjadas on-line são frequentes, mas associadas a afirmações de que "ainda vale a pena tentar". A valorização do retorno à rede como meio privilegiado para a busca de novas relações parece se justificar porque, para a maioria dos pesquisados, a web é o principal local de sociabilidade em que podem expressar seus desejos e conhecer pessoas em situação similar, mas, sobretudo, porque nela imaginam ter total controle sobre as relações.

Sem perceber, encontram na internet outros homens que partilham a experiência de viver em torno da própria sexualidade e, em especial, de uma compreensão da homossexualidade como algo indissociável do segredo. Assim, as restrições aos seus desejos terminam erotizadas em uma busca de socialização em que exercitam identidades inventadas e experimentações sexuais. Partindo de uma prerrogativa convencionalmente masculina de que têm direito a exercitar sua sexualidade sem se responsabilizarem por quem se envolve com eles, terminam também por se eximir com relação ao sofrimento que venham a causar no parceiro, fato expresso em frases como as de Eduardo: "ele é homem e sabe como isso funciona". Esse "funcionamento" toma como dada a aceitação conjunta dos amantes homens de que a vida em sociedade é e deve permanecer heterossexual.

\section{Um armário brasileiro}

A etnografia em curso parece apontar que a promessa da internet de constituir experiências sexuais prazerosas e seguras termina por inserir esses homens no armário e em suas lógicas tensionadoras. Ao contrário da realidade norte- 
18 SEIDMAN, 2004.

${ }^{19}$ Niaill RICHARDSON, 2009.

${ }^{20}$ Lynne HILLIER e Lyn HARRISON, 2007.

21 PARREIRAS, 2008 americana descrita por Steven Seidman, ${ }^{18}$ também aponta a persistência do armário como experiência básica na vida de muitos homens brasileiros que buscam relações amorosas e sexuais com seus pares, em especial desses que cultuam a masculinidade heterossexual e partilham com a cultura hegemônica a fobia com relação ao "efeminamento". 19 Também diferentemente de estudos sobre adolescentes e jovens em outros países, como o de Hillier e Harrison ${ }^{20}$ ou mesmo o desenvolvido no Brasil por Parreiras, ${ }^{21}$ meus entrevistados não usam a internet para "se assumirem" primeiro on-line e depois vivenciarem publicamente suas relações com outros homens.

A manutenção da vida no armário de meus interlocutores se relaciona, em parte, ao fato de que a maioria deles tem entre 25 e 35 anos e também às suas origens marcadas por visões convencionais sobre gênero e sexualidade. Além disso, meu campo apresenta, por uma questão teórico-metodológica, um retrato distinto dos estudos anteriormente mencionados. Diferentemente das outras investigações, não compreendo o armário como um regime de opressão gay regido por uma dinâmica de escolha individual sobre estar dentro ou fora. O armário é um regime de controle da sexualidade culturalmente criado e subjetivamente incorporado por meio do aprendizado social de quais relações são reconhecidas e visíveis no espaço público e quais são punidas ou, na melhor das hipóteses, toleradas apenas quando restritas à invisibilidade e ao privado.

A interpretação do armário como opressão externa a desejos individuais autônomos persiste devido à dificuldade em compreender que ele é um sofisticado regime social de controle da sexualidade que depende da adesão dos próprios sujeitos, os quais, como membros de uma cultura, não detêm o poder de recusá-la a partir de uma decisão individual. Além disso, em nossa sociedade, o armário mantém a doxa corrente que vê o desejo sexual como sendo necessariamente dirigido apenas a um ou outro sexo. Trata-se de um termo já antigo que alude a um conjunto de normas e convenções sociais que classifica e hierarquiza as relações como lícitas ou ilícitas, puras ou impuras.

O contato com as experiências de meus colaboradores me impôs refinar o que compreendia como armário, superando as definições forjadas a partir de experiências de outras épocas, em contextos europeus e norte-americanos, pois o regime de visibilidade em que se inserem obedece a convenções culturais próprias à nossa sociedade e à nossa época. Neste artigo, ensaio uma análise muito preliminar desse armário brasileiro contemporâneo que, compreendido como algo social e histórico, é composto de convenções sobre sexualidade e gênero que marcam não apenas as 
${ }^{22}$ Para uma análise mais detalhada do armário na perspectiva ensaiada aqui, consulte MISKOLCl, 2012
${ }^{23}$ Raewyn CONNELL, 1992, p. 748. vidas dos homens com os quais travei contato, mas também as de todos nós. Buscando transferir o foco dos sujeitos para as normas e as convenções culturais com as quais buscam negociar seus desejos, a investigação tem apontado que a heterossexualidade e a homossexualidade, em vez de opostas e autoexcludentes, se constituem relacionalmente por meio de eixos que mal começamos a explorar. ${ }^{22}$

É um desses eixos que marcam as vidas de meus interlocutores. Usuários como os Machos e os Brothers, nascidos e criados dentro de uma cultura que valoriza e reconhece a masculinidade apenas em sua forma heterossexual e hierarquicamente superior à feminilidade, encontram na internet um local de socialização que lhes acena com a promessa tecnológica de que, on-line, sua autonomia pode se impor às regras sociais, permitindo que vivenciem seus desejos por outros homens sem colocar em risco seu status heterossexual. Marcados por sua formação tradicional e sintonizados com a tecnologia disponível, buscam criar, por meio do contato on-line, uma vida paralela em que vivenciariam seus desejos por outros homens, mantendo intocada a vida socialmente reconhecida e visível. Na prática, observei que as relações forjadas pela internet terminam por interferir na vida oficial, cruzando-a a todo momento. Assim, o procurado contato "real" termina por prover tanto prazer quanto tensão, pois a partir do momento em que passam a conviver com outro homem, também passam a vivenciar insegurança.

$\mathrm{Na}$ internet, seu principal local de socialização homoerótica, o culto da masculinidade hegemônica equivale à criação de uma forma de desejo por ela. O desejo que os guia está na masculinidade padrão corporificada na imagem de um homem plenamente ajustado à ordem heteronormativa. Assim, seu desejo é homoerótico, mas se dirige ao homem "heterossexual" e aos valores e às práticas de uma masculinidade historicamente construída, alçando-os a uma superioridade em relação aos claramente homossexuais, assim como à partilha do controle sobre as mulheres. Esse aparente paradoxo se desfaz se recordamos a asserção de R. W. Connell ${ }^{23}$ de que a masculinidade hegemônica é definida como exclusivamente heterossexual, assim como investigações recentes demonstram como a maioria dos que se envolvem com pessoas do mesmo sexo tende a buscar a conformação aos valores dominantes em busca de aceitação social e familiar.

As histórias de meus colaboradores provam que a internet não é uma ferramenta neutra. Ela os atrai, entre várias razões, pela possibilidade de iniciar relações "do zero", ou seja, nas quais podem controlar toda a informação a ser fornecida para o parceiro em potencial, criando uma versão melhorada de si mesmos. Essa mesma vantagem também 
costuma se associar a um aspecto negativo, o fato de que a rede "sexualiza" suas vidas, aumenta numericamente os contatos e acelera as relações. A rede cria intimidade rápida, levando logo a telefonemas, contatos face a face e encontros sexuais, mas essa facilidade também parece tornar efêmeros os relacionamentos.

Além disso, a web tem modificado suas vidas ao fazer com que, buscando realizar seus desejos, ampliem o papel da sexualidade na forma como se compreendem. São frequentes as observações de como passaram a ter outra relação com seus próprios corpos, passaram a aparar ou depilar os pelos, dedicaram-se a exercícios físicos, passaram a ter "mais desejo sexual", mas a principal transformação parece-me subjetiva e se expressou em duas formas principais de compreender a si mesmo.

Para alguns, a internet os faz falar incessantemente sobre seu desejo, o que constitui um exercício subjetivo que reitera a visão de que seus desejos homoeróticos não passam de "sexualidade", pensamento reconfortante para homens que são incentivados desde a infância a separar amor de sexo. O reconforto da divisão sexo/amor estaria na aceitação da ordenação da vida amorosa como aceitável desde que construída como heterossexual (e quiçá reprodutiva) no espaço público da vida familiar e do trabalho e homo-orientada apenas em segredo, desvinculada de afetividade ou compromisso duradouro. Daí muitos procurarem o que um de meus entrevistados, nascido em uma família tradicional e que se apresentava on-line como Brow, definiu como "um cara macho, normal, que apenas também curta uma parada na encolha com outro brother", ou seja, um parceiro que partilhe de uma concepção bem convencional e sexista do que é ser homem. Para eles, homem sempre tem uma parceira mulher e também amantes, pois a predação sexual e a manipulação da parceira constituem sua própria masculinidade.

Para outros, os quais afirmavam buscar relações duradouras e vincular sexo e amor, era perceptível a prioridade que atribuem ao sexo e aos tipos corporais dos homens com os quais se envolviam. Caio, por exemplo, progressivamente passou a se dedicar a exercícios físicos e, quando terminou com a última namorada, se envolveu com um personal trainer, um rapaz mais jovem e musculoso que considerava "masculino", ainda que um olhar mais atento associá-lo-ia a uma Barbie, um homem gay que busca adquirir masculinidade por meio da construção de um corpo musculoso ou atlético. A relação, curta como é usual entre esses homens, foi sucedida rapidamente por outra similar. Nessa dinâmica, cuja permanência é incerta, ele vive há mais de um ano associando uma vida profissional e familiar hétero com uma rede de camaradas que mantém sua sexualidade em segredo. 
${ }^{24}$ Wilza VILLELA, 1998.

Quando estão se relacionando, ao mesmo tempo, com uma mulher e um homem, muitos, como Eduardo, não expressam sofrimento ou consciência pesada em relação à namorada ou ao amante, mas alguns, como Alex, afirmam ter crises de consciência, o que não os exime de efetivamente enganar e/ou manipular suas companheiras e eventuais amantes. Aparentemente buscando preservar suas namoradas, muitas das quais dizem amar ou respeitar, terminam por traí-las com homens com os quais - mais raramente-também chegam a se envolver. Revelando ou não a eles sua condição de compromissados com uma mulher, tendem a relegá-los aos tempos livres da agenda oficial e exigir deles maior flexibilidade do que oferecem, omitir quase tudo de suas vidas para se preservarem e se afastarem quando sentem seu status heterossexual ameaçado.

Inseridos na cultura brasileira, são marcados pela expectativa de que, como "homens de verdade", deem vazão aos seus desejos, mas sem perder o controle. ${ }^{24} \mathrm{~A}$ lógica acionada para a expressão ou a afirmação dessa masculinidade é a do beber muito, mas sem perder o domínio sobre si mesmo; a do comer bastante, mas sem passar mal; a de fazer muito sexo, mas sem deixar que isso intervenha ou atrapalhe sua vida profissional e familiar. Assim, procuram por outros homens para realizar seus desejos, mas buscam compensar o perigo da exposição nos contatos com eles por meio de um controle redobrado sobre a companheira e o amante. Isso se revela cansativo, já que dependem do convencimento da mulher e ainda mais do homem, do qual esperam compreensão e conformidade às suas demandas.

Conformar-se à masculinidade anteriormente descrita prova-se um exercício difícil e que gera constante tensão psíquica. Vivendo sob o risco de que alguém descubra suas relações com outros homens, alguns parecem desenvolver um comportamento regido por um temor persecutório que os torna incapazes de confiar em alguém. Nessa condição dolorosa e tensa, ainda têm que aprender a controlar seus sentimentos para não despertar suspeitas, o que explica - ao menos em parte - a aparente insensibilidade ou indiferença com que lidam com algumas pessoas. $O$ imperativo social da manutenção da imagem reconhecida na família e no trabalho se impõe à custa de tudo o mais, inclusive de seus próprios sentimentos.

Não tive acesso direto a suas mulheres e pouco obtive de informação a respeito delas enquanto travei contato frequente com rapazes que se envolveram com Machos e Brothers. Elas, do pouco que pude inferir, parecem ignorar realmente as relações de seus companheiros com outros homens, algo compreensível, ao menos em parte, devido à condição de oficialidade adquirida por serem apresentadas 
${ }^{25}$ Da numerosa e rica produção recente sobre as homossexualidades brasileiras contemporâneas, destaco as de Tiago DUQUE, 2010; PELÚCIO, 2009; e SIMÕES FRANÇA e Marcio MACEDO, 2010 à família e partilharem dos eventos e horários mais importantes na vida deles. Os amantes, por sua vez, caracterizamse por aceitar uma posição acessória, o que se justifica por diversas razões, das quais explicito apenas duas: o fato de também terem namorada ou não estarem envolvidos afetivamente com o parceiro. Em uma lógica dolorosa para eles, quanto mais se envolvem, mais passam a demandar atenção, colocando o relacionamento em risco ao pressionar o parceiro que tem como prerrogativa jamais ceder aos anseios de outro homem.

O amor entre os amantes homens frequentemente é percebido por um dos parceiros como ameaça a seu status heterossexual. Problemática, por exemplo, é a posição do parceiro que se separa da namorada, o que tende a evocar no outro o temor de que demande o mesmo dele ou, pior, de que se assuma como homossexual. Raros são os relatos de rompimento, mas muito comuns os sobre perda progressiva de contato. Na fala de um Brow: "se você liga e o cara desconversa dizendo a gente vai se falando... kkkkk [risos] [... ] o cara tá te dando o pé na bunda". Também são comuns os "desaparecimentos", o que a fala de um ex-parceiro de um rapaz que se apresentava como Macho auxilia a entender: "Homem não rompe, esfria, se afasta ou torna sua vida tão ruim até você tomar a iniciativa de cortar contato... Assim ele joga a culpa pelo fim da relação pra você".

Em meio à diversidade de vivências da homossexualidade no Brasil contemporâneo, ${ }^{25}$ as de usuários de internet que se apresentam como Macho ou Brother afirmam ser "fora do meio" e buscam parceiros "acima de qualquer suspeita", demonstram a continuidade das relações com outros homens em segredo, mas, especialmente, da associação da homossexualidade com o ilícito e impuro. É possível especular se alguns desses homens, em um período pré-internet, buscariam contatos sexuais anônimos em locais de pegação, o que a maioria afirma nunca ter feito. Suas visões negativas sobre aqueles que contratam garotos de programa ou que saem com prostitutas sugerem o uso da internet em busca de relações que consideram "limpas". Marcados por valores familiares, tendem a procurar parceiros "fixos" ou, ao menos, não pagos. Assim, a internet os auxilia na constituição de uma relação com um parceiro homem no lugar da tradicional amante.

A rede ampliou o espaço para esses tipos de relações, as quais buscam recriar em um contexto similar ao da camaradagem em que aprenderam a ver reconhecida sua masculinidade heterossexual. Nessa outra camaradagem, testemunhei muitas "amizades" se formarem apenas em torno do desejo compartilhado por outros homens e também na forma como parte dos usuários relatam tentativas frustradas de tornar contatos altamente sexualizados em outras formas 
de relação. Relações criadas e mantidas em torno do segredo compartilhado sobre a homossexualidade parecem aplacar parcialmente a solidão, mas não a extinguir, porque apenas dividem com outro(s) uma problemática em que permanecem: a difícil arte de manter seu status masculino se envolvendo sexualmente com outros homens.

A partir das observações anteriores, é possível começar a refletir melhor sobre a adesão desses homens às normas e convenções culturais que restringem sua afetividade e que dizem Ihes causar tensão ou sofrimento. A etnografia parece indicar que os usuários que costumam se apresentar como Macho ou Brother vivenciam um armário regido tanto pela sexualidade quanto pelo gênero, pois o valor máximo que cultuam é o da masculinidade heterossexual. Eles temem em si próprios, nos outros e no possível parceiro toda e qualquer forma de "efeminamento". O cerne desse medo é de que a atração por pessoas do mesmo sexo os leve a confrontar a ordem social, perdendo o privilégio do gênero masculino, o que, de certa forma, os exporia a serem humilhados e (mal)tratados como mulheres.

Educados em uma concepção de masculinidade que valoriza a predação sexual desde que não interfira na vida familiar, eles sabem como mulheres são enganadas e manipuladas, conhecimento que os guia, em relações com mulheres ou homens, na busca da manutenção de uma posição de domínio e controle que os proteja de destino similar ao delas. Marcados por um script sexual herdado culturalmente em que a infidelidade tem papel fundamental na consolidação de sua masculinidade, particularmente no universo da camaradagem masculina, passam a lidar com a realidade contemporânea em que a possibilidade de retaliação feminina à infidelidade é maior e, no caso deles, envolvidos com homens, teria consequências piores do que se estivessem envolvidos com outra mulher.

Assim, amedrontados, e possivelmente sem intenção consciente, buscam escapar da temida associação à homossexualidade, o que os obriga a lutar contra seus sentimentos e a desenvolver uma insensibilidade com relação ao parceiro quando ele se apaixona. O apaixonado é o que se expõe, o que revela como a homossexualidade para eles - e para a maior parte dos homens brasileiros - ainda é um termo de acusação e desprestígio do qual buscam se livrar, atribuindo-a ao outro. Nessas relações, o amor de um homem por outro é compreendido como perda de autocontrole e racionalidade. O apaixonado é emasculado, o que o torna gay e, na mente desses homens, perigosamente próximo do temido efeminamento, tornando-o - aos olhos daquele que antes o queria - progressivamente indesejável. 
A maioria dos Machos e Brothers que conheci busca o reconhecimento que a sociedade brasileira atribui apenas àquele frequentemente descrito como "homem de verdade", nosso modelo de masculinidade que é também sinônimo de heterossexual. Marcados pela heteronormatividade e mais conscientes de suas injustiças, tendem a sabotar as relações com outros homens quanto mais elas apontam para alguma forma de comprometimento. Assim, mesmo à custa de eventuais sofrimentos e frustrações, afastam-se do ex-amante, priorizando a vida heterossexual que lhes acena, apesar de tudo, com a aceitação social e familiar.

\section{Referências}

BURBULES, Nicholas. "Rethinking the Virtual". E-Learning, v. 1, n. 2, p. 162-182, 2004.

CHAUNCEY, George. Gay New York. New York: Flamingo, 1995.

CONNELL, Raewyn W. "A Very Straight Gay: Masculinity, Homosexual Experience and the Dynamics of Gender." American Sociological Review, v. 57, p. 735-751, 1992.

DÍAZ-BENÍTEZ, María Elvira. Nas redes do sexo: os bastidores do pornô brasileiro. Rio de Janeiro: Zahar, 2010.

DORNELLES, Jonatas. "O Orkut e a terceira forma de sociabilidade". Ciências Sociais, v. 41, n. 3, p. 163-171, 2006.

DUQUE, Tiago. Montagens e desmontagens. São Paulo: Annablume Editora, 2010.

ERIBON, Didier. Reflexiones sobre la cuéstion gay. Barcelona: Anagrama, 1999.

FOUCAULT, Michel. História da sexualidade I: a vontade de saber. São Paulo: Graal, 2005.

GOLDENBERG, Miriam. Por que homens e mulheres traem? Rio de Janeiro: Best Bolso, 2010.

GREEN, James N. Além do Carnaval: homossexualidade masculina no Brasil do século XX. São Paulo: Unesp, 2000.

GUDELUNAS, David. "Online Personal Ads - Community and Sex: Virtually." Journal of Homosexuality, v. 49, n. 1, p. 1-33, 2005.

HILLIER, Lynne; HARRISON, Lyn. "Building Realities Less Limited than Their Own: Young People Practicing Same-Sex Attraction the Web." Sexualities, v. 10, n. 1, p. 82-100, 2007.

HOLLOWAY, Sarah L.; VALENTINE, Gill. Cyberkids: Children in the Information Age. London: Routledge Falmer, 2003.

LYNN, Michael; BOLIG, Rosemary. "Personal Advertisements: Sources of Data about Relationships." Journal of Social and Personal Relationships, v. 2, p. 377-383, 1985.

MISKOLCI, Richard. Desejo e solidão. Rio de Janeiro: CLAMUERJ, 2008.

"O armário ampliado: notas sobre a sociabilidade homoerótica na era da internet”. Gênero, v. 9, n. 2, p. 171-190, 2009. 
"Desejos em rede: notas sobre segredos e mentiras em relações mediadas digitalmente". In: PELÚCIO, Larissa et al. Gênero, sexualidade e mídia: olhares plurais para o cotidiano. Marília: Cultura Acadêmica Editora, 2012. p. 35-55.

PARREIRAS, Carolina. Sexualidades no ponto.com: espaços e homossexualidades a partir de uma comunidade online. 2008. Dissertação (Mestrado em Antropologia Social) Unicamp, Campinas, 2008.

PELÚCIO, Larissa. Na rede com os T-Lovers: o uso de plataformas da internet como instrumento de pesquisa. São Carlos: 2005. Mimeografado.

Abjeção e desejo: uma etnografia travesti sobre o modelo preventivo de aids. São Paulo: Annablume Editora, 2009.

PERLONGHER, Néstor. O negócio do michê: prostituição viril em São Paulo. São Paulo: Fundação Editora Perseu Abramo, 2008.

PHUA, Voon Chin. "Sex and Sexuality in Men's Personal Advertisements." Men and Masculinities, v. 5, n. 2, p. 178-191, 2002.

PHUA, Voon Chin; KAUFMAN, Gayle. "The Crossroads of Race and Sexuality: Date Selection Among Men in Internet 'Personal' Ads." Journal of Family Issues, v. 24, n. 8, p. 981-994, 2003.

RICHARDSON, Niall. "Effeminophobia, Misogyny and Queer Friendship: The Cultural Themes of Channel 4's Playing it Straight." Sexualities, v. 12, n. 4, p. 525-544, 2009.

SEDGWICK, Eve Kosofsky. "Epistemologia do armário". Cadernos Pagu, n. 28, p. 19-54, 2007.

SEIDMAN, Steven. Beyond the Closet: The Transformation of Gay and Lesbian Life. New York: Routledge, 2004.

SIMMEL, Georg. El secreto y las sociedades secretas. Madrid: Sequitur, 2010.

SIMÕES, Júlio Assis; FRANÇA, Isadora Lins. "Do gueto ao mercado". In: GREEN, James N.; TRINDADE, Ronaldo. Homossexualismo em São Paulo. São Paulo: Unesp, 2005.

SIMÕES, Júlio Assis; FRANÇA, Isadora Lins; MACEDO, Marcio. "Jeitos de corpo: cor/raça, gênero, sexualidade e sociabilidade juvenil no centro de São Paulo". Cadernos Pagu, n. 35, p. 37-78, 2010.

SíVORI, Horácio. A política da visibilidade perante as formas contemporâneas de organização da homossexualidade masculina na América Latina. Belém, 2010. Mimeografado da comunicação apresentada na reunião da ABA.

VILLELA, Wilza. "Homem que é homem também pega aids?". In: ARILHA, Margareth et al. Homens e masculinidades: outras palavras. Rio de Janeiro: Editora 34/ECOS, 1998. p. 129-134. 
[Recebido em 24 de março de 2011 reapresentado em 22 de fevereiro de 2012 e aceito para publicação em 18 de maio de 2012]

\begin{abstract}
Machos and Brothers: An Ethnography about the Closet in Male Homoerotic Relations Created On-line

Abstract: Based on an ethnography with men who introduce themselves as Macho or Brother in chatrooms directed toward a gay and bisexual audience in the city of São Paulo, this article explores how these users articulate different platforms to create secret relationships. These men introduce themselves and search for partners that can be described as "straight acting" and "not part of the gay scene" creating relations shaped by the sexuality control regime known as the closet. This analysis tries to expose gender and sexuality norms that shape these users' closet, or the way they act trying to keep their heterosexual status while also having sexual or love relationship with other men.
\end{abstract}

Keywords: Sexuality; Internet; Secret; Closet; Male Homoerotic Relations; Heterosexual Masculinity. 